\title{
The Impact of Customer Relationship Management on Tourist Satisfaction in Movenpick Resort and Residences in Aqaba, Jordan
}

\author{
Dr. Mohammad Ragab Khashman Al-Laymoun \\ Jordan Applied University (JAU), \\ College of Hospitality and Tourism Education
}

doi: 10.19044/esj.2016.v12n11p318 URL:http://dx.doi.org/10.19044/esj.2016.v12n11p318

\begin{abstract}
This study aims at investigating the impact of customer relationship management on tourist satisfaction in Movenpick Resort and Residences in Aqaba, Jordan. In this research, the Statistical Package for Social Sciences (SPSS) was used for data entry as well as for examining the data. Data preparation was the initial step. It aimed to convert raw data into a more structured format that is more appropriate for analysis. The results show that there is a significant relationship between Marketing activities and tourist satisfaction about the service provided in Movenpick Resort and Residences in Aqaba, Jordan.
\end{abstract}

Keywords: Customer relationship management, tourist satisfaction, Movenpick Resort, marketing, Aqaba

\section{Introduction}

Many service organizations have embraced relationship marketing with its focus on maximizing customer lifetime value. Recently, there is a considerable controversy about whether there is a link between customer satisfaction and retention. However, this research question is important to researchers who are attempting to determine the relationship between customer relationship management and tourist satisfaction in the Movenpick Resort and Residences in Aqaba, Jordan.

Customer satisfaction ratings elicited prior to any decision to cancel or stay loyal to the provider are positively related to the duration of the relationship. The strength of the relationship between duration times and satisfaction levels depends on the length of the customers' prior experience with the organization. Customers who have several months of experience with the organization have more satisfaction and can provide new information (relatively). The duration of the service provider-customer 
relationship also depends on whether customers experienced service transactions or failures. The effects of perceived losses arising from transactions or service failures on duration times are directly weighed by prior satisfaction. Hence, this creates contrast and assimilation effects. However, it is equally vital to managers who require a better understanding of the relationship between satisfaction and the duration of the providercustomer relationship to identify specific actions that can increase retention and profitability in the long run. Since there is very little empirical evidence regarding this research question, this study develops and estimates a dynamic model of the duration of the provider. This provider entails customer relationship that focuses on the role of customer satisfaction.

Consequently, the relationship is likely to be very short. There is considerable heterogeneity across customers because some customers have a higher utility for the service than others. However, certain types of service encounters are potential relationship "landmines". This is based on the fact that customers are highly sensitive to the costs/losses arising from interactions with service organizations. Thus, they are insensitive to the benefits/gains. Furthermore, incidence and quality of service encounters can be early indicators of whether an organization's relationship with a customer is flourishing or can be said to be in jeopardy. Unfortunately, organizations with good prior service levels will suffer more when customers perceive that they have suffered a loss arising from a service encounter-due to the existence of contrast effects. However, experienced customers are less sensitive to such losses because they tend to weigh prior satisfaction levels heavily (Jawabreh, 2014). It was discovered that the hotel in Aqaba use specialized Customer Relationship Management (CRM) software to manage customers. In addition, the hotel makes use of specialized Customer Relationship Management (CRM) Software to improve its ability to manage customers. This was to the extent that staffs have to follow some specific guidelines to work together as a team.

Based on the theory from consumer behavior and cognitive psychology, the purpose of this paper is to discuss and test corporate image and customer satisfaction as two routes to customer loyalty. Based on data from 600 individuals, customers have been categorized as having high or low service expertise of three companies within the package tour industry. In addition, a conceptual model is proposed and tested empirically using structural equation modeling. The data used in the study are included in The Norwegian Customer Satisfaction Barometer. The paper concludes by claiming that for complex services, corporate image and customer satisfaction are not two separate routes to customer loyalty. However, corporate image impacts customer loyalty directly, whereas customer satisfaction does not. This finding is consistent with high and low service 
expertise. These results challenge the disconfirmation paradigm which predicts customer satisfaction to be the primary route to customer loyalty. From a managerial perspective, information regarding the relative strength of the two routes is vital with regard to resource allocation for the purpose of improving customer loyalty.

\section{Literature Review}

Both the service management and the marketing literatures suggest that there is a strong theoretical underpinning for an empirical exploration of the linkages among customer satisfaction, customer loyalty, and profitability. The relatively small quantity of empirical research performed on these relationships to date (Storbacka et al., 1994) is probably the result of the paucity of organizations" measuring "soft" issues, such as customer satisfaction and customer loyalty, in meaningful ways.

The service management literature argues that customer satisfaction is the result of a customer's perception of the value received in a transaction, or is the relationship where value equals perceived service quality relative to price and customer acquisition costs (Blanchard \& Galloway, 1994; Heskett et al., 1990). Therefore, this is relative to the value expected from transactions or relationships with competing vendors (Zeithaml et al., 1990). Loyalty behaviors, including relationship continuance, increased scale or scope of relationship, and recommendation (word of mouth advertising) result from customers' beliefs that the quantity of value received from one supplier is greater than that available from other suppliers. Loyalty, in one or more of the forms noted above, creates increased profit through enhanced revenues, reduced costs to acquire customers, lower customer-price sensitivity, and decreased costs to serve customers who were familiar with a firm’s service delivery system (Reicheld \& Sasser, 1990).

The marketing literature suggests that customer loyalty can be defined in two distinct ways (Jacoby \& Kyner, 1973). The first defines loyalty as an attitude. Therefore, different feelings create an individual's overall attachment to a product, service, or organization (see Fornier, 1994). These feelings define the individual's (purely cognitive) degree of loyalty. Tauseef noted that the information customers get from the hotel is accurate. The hotel always exerts good efforts to fulfill its promises, so that the customers could get the hotels services as promised.

The second definition of loyalty is behavioral. Examples of loyalty behavior include continuing to purchase services from the same supplier, and increasing the scale or scope of a relationship, or the act of recommendation (Yi, 1990). The behavioral view of loyalty is similar to loyalty as defined in the service management literature. This study examines behavioral loyalty, rather than attitudinal loyalty (such as intent to repurchase). This approach is 
intended, first, to include behavioral loyalty in the conceptualization of customer loyalty that has been linked to customer satisfaction. Secondly, it aims in making the demonstrated satisfaction/loyalty relationship immediately accessible to managers that are interested in customer behaviors linked to the firm's performance.

Satisfaction levels explain a substantial portion of explained variance in the durations of service provider. This is the customer relationships across customers which is comparable to the effect of price. Consequently, it is a popular misconception that organizations that focus on customer satisfaction are failing to manage customer retention. As a result, this article suggests that service organizations should be proactive and learn from customers before they experience defect in understanding their current satisfaction levels. Therefore, managers and researchers may have underestimated the importance of the link between customer satisfaction and retention. This is based on the fact that the relationship between satisfaction and duration times is very complex and difficult to detect without advanced statistical techniques.

An understanding of how to manage relationships with customers effectively has become an important topic for both academicians and practitioners in recent years. However, the existing academic literature and the practical applications of customer relationship management (CRM) strategies do not provide a clear indication of what specifically constitutes CRM processes. In this study, the authors (1) conceptualize a construct of the CRM process and its dimensions, (2) operationalize and validate the construct, and (3) empirically investigate the organizational performance consequences of implementing CRM processes. Consequently, their research questions are addressed in two cross-sectional studies across four different industries and three countries. The first key outcome is a theoretically sound CRM process measure that outlines three key stages: initiation, maintenance, and termination. The second key result is that the implementation of CRM processes has a moderately positive association with both perceptual and objective company performance.

A normal way of monitoring customer satisfaction and success is to look at the market share and to undertake ad hoc customer satisfaction surveys. A stable or rising share of the market is considered as a measure of success and indirectly as customer satisfaction. When the customer base remains stable, market share serves as a good measurement of satisfaction. However, very often, one does not know whether it is in fact stable, or whether the firm is losing a fair share of its customers who are replaced by new customers. This was done by means of aggressive marketing and sales. In such situations, following market share statistics only may easily give a false impression of success, when in fact the number of unsatisfied 
customers and ex-customers is growing and the image of the firm is deteriorating.

For a consumer packaged goods marketing firm, which typically would apply a transaction marketing strategy, there are no ways of continuously measurement of the market success other than monitoring market share. A service firm and many industrial marketers, on the other hand, who more easily could pursue a relationship marketing strategy, have at least some kind of interactions with almost every single customer, even if they serve mass markets. Thus, customer satisfaction can be monitored directly. Furthermore, a firm that applies a relationship-type strategy can monitor customer satisfaction by directly managing its customer base [16]. Managing the customer base means that the firm has at least some kind of direct knowledge of how satisfied its customers are. Instead of thinking in anonymous numbers or market share, management thinks in terms of people with personal reactions and opinions. This requires a means of gathering the various types of data about customer feedback that are constantly, every day, obtained by a large number of employees in large numbers of customer contacts. In combination with market share statistics, such an intelligence system focusing on customer satisfaction and customer needs and desires forms a valuable source of information for decision making.

Consequently, in a relationship marketing situation, the firm can build up an online and a real time information system. This system will provide management with a continuously updated database of its customers and continuous information about the degree of satisfaction and dissatisfaction among customers. This can serve as a powerful management instrument. In a transaction marketing situation, it is impossible, or at least very difficult and expensive, to build up such a database.

It is a marketplace reality that marketing managers sometimes inflict switching costs on their customers. This they do to inhibit them from defecting to new suppliers. In a competitive setting, such as the Internet market, where competition may be only one click away, marketing managers has the potential of switching costs as an exit barrier and a binding ingredient of customer loyalty. To address that issue, this article examines the moderating effects of switching costs on customer loyalty through both satisfaction and perceived-value measures. The results, evoked from a Webbased survey of online service users, indicate that companies that strive for customer loyalty should focus primarily on satisfaction and perceived value. The moderating effects of switching costs on the association of customer loyalty, customer satisfaction, and perceived value are only significant when the level of customer satisfaction or perceived value is above average. In light of the major findings, the article sets forth strategic implications for customer loyalty in the setting of electronic commerce. 
Many firms that are frustrated in their efforts to improve quality and customer satisfaction are beginning to question the link between customer satisfaction and economic returns. However, the authors investigate the nature and strength of this link. They discuss how expectations, quality, and price should affect customer satisfaction and why customer satisfaction, in turn, should affect profitability. Thus, this results in a set of hypotheses that are tested using a national customer satisfaction index and traditional accounting measures of economic returns, such as return on investment. The findings support a positive impact of quality on customer satisfaction, and, in turn, profitability. The authors demonstrate the economic benefits of increasing customer satisfaction using both an empirical forecast and a new analytical model. In addition, they discuss why increasing market share actually might lead to lower customer satisfaction and provide preliminary empirical support for this hypothesis. Finally, two new findings emerge. First, the market's expectations of the quality of a firm's output positively affect the customers' overall satisfaction with the firm. Second, these expectations are largely rational, albeit, with a small adaptive component.

Research that investigated their use of the Internet to verify whether customer relationship marketing was being implemented within online operations or whether their Internet presence merely revolved around the basic functions of "providing information" and "hotel reservations" was incorporated (Diana Luck \& Geoff Lancaster, 2003) (E-CRM). The findings and subsequent discussion showed that on the Internet, hotel groups used their relationship with customers to provide information rather than gather information. The majority of the hotel groups had only embraced a few elements of E-CRM and even indicated that they did not intend to be lead online by the concept. Although the findings of the questionnaire indicated that hotel groups were generally aware of the potential of Web technologies and strategies, they also showed that companies were not putting this knowledge into practice when it comes to implementing E-CRM. Primary research concluded that hotel groups based in the UK were failing to take advantage of the many opportunities identified through the secondary research.

George S. Day (2000) creates and maintains relationships with their most valuable customers. Hence, this serves as a durable basis for a competitive advantage. To keep this edge over rivals, who continually try to attract these customers away, a firm has to master the three elements of a market-relating capability. First, a relationship orientation must pervade the mind-set, values, and norms of the organization. Second, the firm must keep deepening its knowledge of these customers and keep putting it to work throughout the organization. Third, the key processes must be internally 
integrated and externally aligned with the corresponding processes of the firm's customers.

\section{The Problem of the Study}

The study attempts to answer the following question:

1- What is the contribution of Relationship Marketing to build customer satisfaction and earn their loyalty?

2- $\quad$ Is there a trace of marketing relations on customer satisfaction?

3- What is the nature of the relationship between Relationship Marketing and customer loyalty?

4- What is the reality of the exercise of Relationship Marketing in Mövenpick Hotel, Aqaba, from the viewpoint of its customers?

\section{Research Importance}

The importance of the marketing of services and customer satisfaction cannot be overemphasized. This is due to their prominent role in the success of an organization, and their ability to grow and continue to work in addition to raising the efficiency of these organizations. Consequently, it is used in the implementation of its functions efficiently and effectively. In addition, it is used to identify the scientific reality of the effect of marketing services on the decisions of the customers at the sample that was researched. Furthermore, it also put into consideration their impact on customer value, particularly after a lot of challenges and problems have emerged. These problems usually occur due to globalization and the tremendous development in this area which requires a new approach in terms of management and performance alike.

\section{Data Analysis}

In this research, the Statistical Package for Social Sciences (SPSS) was used for data entry as well as for examining the data later. Data preparation was the initial step. This is aimed to convert raw data into a more structured format that is more appropriate for analysis. The various tasks in this stage included data editing, data coding, and data entry. Descriptive statistics were used to summarize respondent's characteristics, including demographic information, such as age, gender etc. Also, questions about the participating company's profile, such as the numbers of customers, were included. Furthermore, inferential statistics were used to test hypothesis to determine the relationship between variables. In particular, Pearson Correlation was used to verify the association of the interval level to the construct. On the other hand, Chi-square was used to validate the association between nominal variables and the construct. Moreover, the Cronbach coefficient alpha was used for reliability tests. Lastly, the variable analysis 
tool, analysis of variance (ANOVA), was used to determine the relationship between the effects of customer relationship management with tourist satisfaction in the Movenpick Resort and Residences in Aqaba, Jordan.

\section{Hypothesis}

1- There is a relationship between marketing activities and tourist feeling good about the service provided in Movenpick Resort and Residences in Aqaba, Jordan

2- There is a relationship between marketing activities and communication with tourists in Movenpick Resort and Residences in Aqaba, Jordan.

3- There is a relationship between marketing activities and the trust and loyalty among tourist in Movenpick Resort and Residences in Aqaba, Jordan.

\section{The Movenpick Resort and Residences in Aqaba}

Mövenpick Hotels and Resorts have evolved into a highly regarded upscale hotel management company since its founding in 1973. Today, it counts among the 50 leading hotel groups in the world. Today, we have over 100 hotels existing or under construction in the core markets of Europe, Africa, the Middle East, and Asia. Thus, these hotels employ over 14,000 people worldwide. Traditional Swiss values, such as quality, reliability, and care with a personal touch, are offered in all the hotels. This was established so that the annual guest of mostly six million would feel very well taken care of.

The Movenpick Resort and Residences, Aqaba, is located at the centre of Aqaba, right on the northern sandy beach of the Gulf of Aqaba on the Red Sea. However, this architectural delight features a mix of European and Arabesque designs, reflecting a homely feeling. The resort combines grandeur, luxury, and also welcomes hospitality. One of the over 296 rooms, as well as 87 suites and apartments, all offers a luxurious and comfortable stay. Contemporary design and neutral tones give the rooms a modern feel and flashes of colour influenced by the sky, sea, and surrounding land which are pleasing to the eye. All of the rooms and suites come equipped with the modern amenities one would expect for a trip of a lifetime.

\section{Stability of the Measure}

Statistical Methods Used and Test Hypothesis

Several statistical measures were used to calculate the arithmetic mean, t test, Cronbach's alpha test, standard deviation, and $\mathrm{F}$ test. 
The hypothesis tested was a standard reject hypothesis. Hence, this is said to be the arithmetic mean which is greater than 3 . Also, to even be of significant value, it must be greater than t tabular value or must have a significance level of less than 0.05 scenes. The fourth hypothesis was tested using $\mathrm{t}$ and $\mathrm{f}$, based on the differences resulting from personal variables.

\section{The Stability of the Tool}

Consequently, the stability of the measure was tested using Cronbach's alpha coefficient. Thus,

Table (1) shows:

1. The value of alpha paragraphs dimension satisfied with the service provided 0.67 .

2. The value of alpha paragraphs dimension to communicate with customers 0.82 .

3. The value of alpha paragraphs dimension of trust and loyalty 0.85 .

4. The value of alpha for all the combined paragraphs 0.91 .

As a result, there is stability in the study tool because all of these values is greater than 0.60 .

Table 1. Alpha cronbach's values

\begin{tabular}{|c|c|}
\hline Dimension & Alpha \\
\hline Satisfaction with the service provided & 0.67 \\
\hline Contact with customers & 0.82 \\
\hline Trust and loyalty & 0.85 \\
\hline Total & 0.91 \\
\hline
\end{tabular}

Table 2. Description of demographic factors and personal to the respondents

\begin{tabular}{|c|c|c|}
\hline Factor & Frequency & Percentages \\
\hline \multicolumn{3}{|l|}{ Gender } \\
\hline \multirow{2}{*}{$\begin{array}{c}\text { Male } \\
\text { Female }\end{array}$} & 59 & $59.6 \%$ \\
\hline & 40 & $40.4 \%$ \\
\hline \multicolumn{3}{|l|}{ Age } \\
\hline \multirow{5}{*}{ 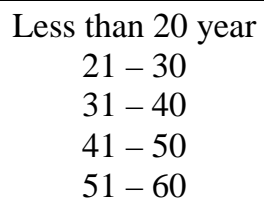 } & 16 & $6.1 \%$ \\
\hline & 42 & $11.3 \%$ \\
\hline & 12 & $17.4 \%$ \\
\hline & 15 & $11.7 \%$ \\
\hline & 14 & $27.4 \%$ \\
\hline \multirow{5}{*}{$\begin{array}{l}\text { Monthly income } \\
\text { Less than 300JD } \\
\text { 301- 500JD } \\
\text { 501-600 JD } \\
\text { More than 601JD }\end{array}$} & & \\
\hline & 32 & $32.3 \%$ \\
\hline & 25 & $25.3 \%$ \\
\hline & 15 & $15.2 \%$ \\
\hline & 27 & $27.3 \%$ \\
\hline \multicolumn{3}{|l|}{ Occupation } \\
\hline \multirow{2}{*}{$\begin{array}{l}\text { Private sector } \\
\text { Public sector }\end{array}$} & 35 & $36.64 \%$ \\
\hline & 64 & $63.35 \%$. \\
\hline Education & & \\
\hline
\end{tabular}




\begin{tabular}{|c|c|c|}
\hline High school & 15 & $15.2 \%$ \\
\cline { 2 - 3 } Bachelors degree & 30 & $30.3 \%$ \\
\cline { 2 - 3 } Master degree & 47 & $47.5 \%$ \\
\cline { 2 - 3 } Postgraduate degree & 4 & $4.0 \%$ \\
\hline
\end{tabular}

The First Hypothesis: There is a relationship between marketing activities and tourist feeling good about the service provided in Movenpick Resort and Residences in Aqaba, Jordan.

Apart from paragraphs No. 5 and No. 7, all other paragraphs circles calculations have reached greater than 3.00. Also, the significance level seems to be less than 0.05 . Therefore, this means that all these paragraphs were statistically significant. Paragraph No. 1 which measure the extent of the tourist feeling good about his dealings with the hotel was ranked first with a mean of 4.59. Paragraph No. 6, which measure the extent of the treatment of workers in the hotel ranked last on the paragraphs. It is accepted and has a mean of 3.64.

Paragraph No. 5, which measure the extent of the feeling of tourists as a partner in the hotel and not just tourists, has reached a mean 2.91. Thus, this means that there is a sense of belonging of the resident tourists in the hotel.

Paragraph No. 7 which measure the extent of favorable hotel compared to Aqaba at tourist hotels through his personal experience at the center has reached a mean of 2.80. Thus, this means that they have no preference for this hotel.

The all paragraphs combined together amounted to mean a 3.93. The level of significance viewer was 0.00. Thus, this means that the first hypothesis is accepted. Also, there is a significant relationship between marketing activities and tourist feeling good about the service provided in Movenpick Resort \& Residences in Aqaba.

Table 3. Mean, Std. Deviation, T-test, and sig to advertising

\begin{tabular}{|c|c|c|c|c|c|}
\hline No & Paragraph & Mean & $\begin{array}{c}\text { Std. } \\
\text { Deviation }\end{array}$ & t-test & Sig. \\
\hline 1 & I feel good about this hotel & 4.59 & 0.62 & 25.33 & 0,00 \\
\hline 2 & I feel proud when I deal with this hotel & 4.20 & 0.73 & 16.43 & 0,00 \\
\hline 3 & I respect and value the hotel & 4.26 & 0.84 & 14.95 & 0,00 \\
\hline 4 & Style hotel staff treats me comfortably & 4.12 & 1.05 & 10.60 & 0,00 \\
\hline 5 & $\begin{array}{c}\text { The hotel makes me feel that I am a partner and } \\
\text { not just a tourist }\end{array}$ & 2.91 & 1.20 & $0.75-$ & 0,00 \\
\hline 6 & $\begin{array}{c}\text { Staffs in the hotel make me want to deal with } \\
\text { hotel and not others }\end{array}$ & 3.64 & 0.96 & 6.57 & 0,00 \\
\hline 7 & $\begin{array}{c}\text { Based on my personal experience of the hotels } \\
\text { in Aqaba, this hotel is the best one }\end{array}$ & 2.80 & 1.26 & $1.59-$ & 0,00 \\
\hline 8 & $\begin{array}{c}\text { I would recommend my friends to deal with } \\
\text { this hotel for its Premium Services }\end{array}$ & 3.79 & 0.91 & 8.65 & 0,00 \\
\hline 9 & $\begin{array}{c}\text { Staff in the hotel offers me the information that } \\
\text { I need on a timely basis }\end{array}$ & 4.15 & 0.76 & 15.06 & 0,00 \\
\hline
\end{tabular}




\begin{tabular}{|c|c|c|c|c|c|}
\hline 10 & $\begin{array}{c}\text { Staff groups in the hotel offers me all that is } \\
\text { new from the services offered in the hotel. }\end{array}$ & 4.13 & 0.74 & 15.26 & 0,00 \\
\hline Total & 3.86 & 0.54 & 15.89 & 0,00 \\
\hline
\end{tabular}

The Second Hypothesis: There is a relationship between marketing activities relations and communication with tourists in Movenpick Resort and Residences in Aqaba, Jordan.

From Table 3, apart from paragraphs 13 and 16, the other paragraph which contains the calculation is greater than 3.00. The level of significance viewing each of them is less than 0.05. However, this means that all these paragraphs are statistically significant. Paragraph No. 14 which measure whether the workers at the hotel are making the maximum effort to maintain the relationship with tourists came to the first rank. Thus, it has a mean of 3.97. Paragraph No. 11, which measures the extent to characterize this hotel without constant contact with other tourists, ranked last in the paragraphs. Hence, this was accepted with a mean of 3.26.

Paragraph No. 13 measures the pursuit of workers in the hotel to a deep understanding of the needs of customers. The market reached a mean of 2.80, meaning that there is no quest for workers in the hotel to a deep understanding of the needs of customers.

Paragraph No. 16 measures the extent to distinguish treatment; however, this makes the hotel flexible. The center has reached its calculations of 2.80, which means it lacks flexibility.

All paragraphs that were combined amounted to a mean of 3.38, and the level of significance viewer was 0.00 . Therefore, this means that the second hypothesis was accepted, that is, there is a relationship between marketing activities relations and communication with tourists in Movenpick Resort and Residences in Aqaba, Jordan.

Table 4. Mean Std. Deviation, T-test, and sig promotion through Advertising

\begin{tabular}{|c|c|c|c|c|c|}
\hline No & Paragraph & Mean & $\begin{array}{c}\text { Std. } \\
\text { Deviation }\end{array}$ & t-test & Sig. \\
\hline 11 & This hotel has no other constant contact with tourists & 3.26 & 2.35 & 1.11 & 0,00 \\
\hline 12 & $\begin{array}{c}\text { The workers in the hotel proffer solution to the } \\
\text { customers' needs from time to time }\end{array}$ & 3.96 & 0.88 & 10.85 & 0,00 \\
\hline 13 & $\begin{array}{c}\text { Staff in the hotel seek a deep understanding of the } \\
\text { needs of customers }\end{array}$ & 2.80 & 1.67 & $1.21-$ & 0,00 \\
\hline 14 & $\begin{array}{c}\text { Make hotel workers in the maximum effort to } \\
\text { maintain the relationship with the tourists }\end{array}$ & 3.97 & 0.96 & 10.02 & 0,00 \\
\hline 15 & Workers in the hotel often responds to my needs & 3.96 & 0.73 & 13.13 & 0,00 \\
\hline 16 & Treatment provided by this hotel is flexible & 2.35 & 1.28 & $5.02-$ & 0,00 \\
\hline & Total & 3.38 & 0.68 & 5.66 & 0,00 \\
\hline
\end{tabular}

The Third Hypothesis: There is a relationship between marketing activities and the trust and loyalty among tourist in Movenpick Resort and Residences in Aqaba. 
From Table 5, apart from paragraphs No. 17 and No. 26, the other paragraph that contains the calculation is greater than 3.00, and the level of significance viewing each of them is less than 0.05 . Therefore, this means that all of these paragraphs are statistically significant. Paragraph No. 25 which measure whether building strong relationships with customers can get responsibility among all employees of the hotel was ranked first with a mean of 4.28. Paragraph No. 18, which measure the extent that workers in the hotel sought to provide personal services to suit the needs of the tourist was ranked last on the paragraphs. It is statistically acceptable and it has a mean of 3.69 .

Paragraph No. 17 which measure whether the Staff at the hotel tourist's problems are trying to find appropriate solutions, has reached a mean of 2.91. Therefore, it is not statistically significant.

Paragraph No. 26 measures the extent of the feeling of tourist's continuous improvement in the development of the services provided by the hotel. Although the center of his calculations was 3.06, the level of significance is that the viewer is greater than 0.05 . Thus, there is no significant development.

All the paragraphs combined together amounted to a mean of 3.76, and the level of significance viewer was 0.00 . Therefore, this means that the third hypothesis was accepted, and there is no relationship between marketing activities and the trust and loyalty among tourists in Movenpick Resort and Residences in Aqaba, Jordan.

Table 5. Mean, Std. Deviation, T-test, and sig to promotion through personal selling

\begin{tabular}{|c|c|c|c|c|c|}
\hline No & Paragraph & Mean & $\begin{array}{c}\text { Std. } \\
\text { Deviation }\end{array}$ & T-test & Sig. \\
\hline 17 & $\begin{array}{l}\text { Staff at the hotel are trying to find appropriate solutions } \\
\text { to tourist's problems }\end{array}$ & 2.91 & 1.44 & $0.63-$ & 0.53 \\
\hline 18 & $\begin{array}{c}\text { Staff at the hotel seeks to provide personal services to } \\
\text { suit the needs of the tourist }\end{array}$ & 3.69 & 0.78 & 8.79 & 0.00 \\
\hline 19 & Confident about the services provided by the hotel & 3.94 & 0.71 & 13.13 & 0.00 \\
\hline 20 & $\begin{array}{l}\text { Featuring the capacity and efficiency of workers in the } \\
\text { hotel by providing assistance to the customer }\end{array}$ & 4.18 & 0.87 & 13.47 & 0.00 \\
\hline 21 & $\begin{array}{l}\text { Workers in the hotel fulfill their obligations to the } \\
\text { customer }\end{array}$ & 3.98 & 0.78 & 12.46 & 0.00 \\
\hline 22 & $\begin{array}{c}\text { Staffs in the hotel are dealing with the customer without } \\
\text { warning them }\end{array}$ & 3.76 & 1.01 & 7.46 & 0.00 \\
\hline 23 & $\begin{array}{l}\text { The workers has high regards for customers when } \\
\text { dealings with them }\end{array}$ & 3.89 & 0.82 & 10.80 & 0.00 \\
\hline 24 & $\begin{array}{c}\text { Contributes to solving customer problems who are } \\
\text { dealing continuously with this hotel }\end{array}$ & 3.87 & 0.94 & 9.16 & 0.00 \\
\hline 25 & $\begin{array}{l}\text { Building strong relationships with customers is a shared } \\
\text { responsibility among all employees of the hotel }\end{array}$ & 4.28 & 5.17 & 2.47 & 0.00 \\
\hline 26 & $\begin{array}{l}\text { I feel constant improvement in the development of the } \\
\text { services provided by this hotel }\end{array}$ & 3.06 & 1.54 & 0.39 & 0.70 \\
\hline & Total & 3.76 & 0.78 & 9.64 & 0.00 \\
\hline
\end{tabular}




\section{Results}

Therefore, the study shows the following results:

1. There is a relationship between marketing activities and tourist feeling good about the service provided in Movenpick Resort and Residences in Aqaba, Jordan.

2. Tourist did not feel that they are partners in the hotel, but sees themselves as just tourists.

3. Based on personal experience, there is no advantage that this hotel has compared to other tourist hotels in Aqaba.

4. There is a relationship between marketing activities and communication with tourists in Movenpick Resort and Residences in Aqaba, Jordan.

5. There is no quest for workers in the hotel on a deep understanding of the needs of customers. flexible.

6. The treatment provided by this hotel is not characterized to be

7. There is a relationship between marketing activities and the trust and loyalty among tourists in Movenpick Resort \& Residences in Aqaba.

8. The hotel staff does not treat the problems of tourists by trying to find appropriate solutions.

9. They do not feel tourist's continuous improvement in the development of the services provided by the hotel.

\section{Recommendations}

The study recommends the following:

1. Improvement of the hotel is placed in general; and it have a preference for Aqaba hotels to increase turnout.

2. Make the tourists have the feeling that there are partners in the hotel.

3. The need to understand the needs of customers and in trying to meet them to gain more confidence and belonging by tourists.

hotel.

4. Treatment must be characterized by the flexibility provided by the

5. The staff at the hotel should always try to identify the problems of tourists and find appropriate solutions to them.

6 . There is the need for continuous development and improvement in the services provided by the hotel.

\section{References:}

Andreassen et al. (1998). Customer loyalty and complex services: The impact of corporate image on quality, customer satisfaction, and loyalty for 
customers with varying degrees of service expertise, International Journal of Service Industry Management, Volume 9, Number 1, 1998, pp. 7-23(17). Christian Grönroos (1994). From Marketing Mix to Relationship Marketing: Towards a Paradigm Shift in Marketing, Management Decision, Vol. 32 Iss: 2, pp.4-20.

Diana \& Lancaster (2003). E-CRM: customer relationship marketing in the hotel industry, Managerial Auditing Journal, Vol. 18 Iss: 3, pp. 213-231, 10.1108/02686900310469961.

George S. Day (2000). Managing Market Relationships, Journal of the Academy of Marketing Science, January, vol. 28 no. 124-30. http://www.movenpick.com/en/about-us/about-us: 125PM, 2/2/2016.

Jawabreh (2014). The Impact of Customer Relationship Marketing by Aqaba Economic Zone "A Case Study of Five Stars Hotels", International Journal of Academic Research in Accounting, Finance and Management Sciences, vol. 4, issue 1, pages 167-174, DOI: 10.6007/IJARAFMS/v4-i1/583.

Kaj et al. (1994). Managing Customer Relationships for Profit: The Dynamics of Relationship Quality, International Journal of Service Industry Management, Vol. 5 Iss: 5, pp.21 - 38 , http://dx.doi.org/10.1108/09564239410074358.

R.F. Blanchard \& R.L. Galloway (1994). Quality in Retail Banking, International Journal of Service Industry Management, Vol. 5 Iss: 4, pp. 5

23 , http://dx.doi.org/10.1108/09564239410068670.

Roger Hallowell (1996). The relationships of customer satisfaction, customer loyalty, and profitability: an empirical study", International Journal of Service Industry Management, Vol. 7 Iss: 4, pp.27 - 42, http://dx.doi.org/10.1108/09564239610129931.

Tauseef \& Jawabreh (2012). Impact of Customer Relationship Management of Hotel (A Case study Umaid Bhwan), Asian Journal of Finance \& Accounting, Vol. 4, No. 1, doi:10.5296/ajfa.v4i1.1362.

Werner et al. (2004). The Customer Relationship Management Process: Its Measurement and Impact on Performance. Journal of Marketing Research: August 2004, Vol. 41, No. 3, pp. 293-305.

Youjae (1990). The Effects of Contextual Priming in Print Advertisements, Journal of Consumer Research, Vol. 17, No. 2 , pp. 215-222.

Zhilin \& Robin (2004). Customer perceived value, satisfaction, and loyalty: The role of switching costs, Psychology \& Marketing, Volume 21, Issue 10, pages 799-822. 